\title{
SYMBOLS OF IDENTITY AND CULTURE OF THE MONOGRAM IN THE LATE ANTIQUE MITHRAISM
}

\author{
THE CASE OF OSTIA
}

\begin{abstract}
Summary: The highest number of mithraea in urban context of the ancient world come from Ostia. Although we do not know the whole city, mithraea have been found in all districts of the town. The spread and fortune of the Mithraic worship are also attested by the plenteous epigraphic and sculptural materials. This research deals with the Mithraism at Ostia, focusing on the particular case of monograms, just mentioned by Giovanni Becatti in his seminal work about mithraea at Ostia, dating back to more than sixty years ago. After the recent discovery of the Mithraeum of colored marbles by the archaeologists of the Ostia Marina Project (University of Bologna), it seems necessary to examine and contextualize the phenomenology of Mithraic monograms at Ostia, as is done in relation to similar processes which involve the Christian world.
\end{abstract}

Key words: Mithraism, early Christianity, late Antiquity, ancient Ostia, monograms, Ostia Marina Project

\section{THE WIDESPREAD OF MONOGRAMS BETWEEN THE 3RD AND 4TH CENTURY CE}

Within the Ostia Marina Project, carried out by the University of Bologna since 2007, in the neighborhood located out of Porta Marina, in ancient Ostia, the Mithraic studies deserved a revival thanks to recent discoveries in the complex of the Caupona of god Pan, dated to the mid-3rd century CE, ${ }^{1}$ and of the Mithraeum of the colored

${ }^{1}$ See DAVID, M.: Una caupona tardoantica e un nuovo mitreo nel suburbio di Porta Marina a Ostia antica. Temporis Signa 9 (2014) 31-44; DAVID, M.: Nuovi mosaici pavimentali dalla Caupona del dio Pan a Ostia antica. In Angelelli, C. - MAsSARA, D. - SpOsito, F. (edd): Atti del XXI colloquio dell'Associazione italiana per lo studio e la conservazione del mosaico, Reggio Emilia, 18-21 marzo 2015. Tivoli 2016, 359-367 (with S. De Togni, G. P. Milani, A. Pellegrino, J. Ferrandis Montesinos, M. Carinci). 
marbles, which had been the result of the re-use of the Caupona itself since the late 4th century $\mathrm{CE}^{2}{ }^{2}$

The analysis of the painted surface from the Mithraic phase of this building allowed to recognize several alphabetical graffiti. ${ }^{3}$ Giovanni Becatti, in his corpus of the mithraea of Ostia, had already dealt with Mithraic symbols and monograms.

We recall that the early public evidence of the numerous cults of the Imperial Age and late antique Roman society appears at the time of the reforms enacted by Diocletian and the other Tetrarchs. In these historical circumstances, the religious expression becomes an essential part of the political communication, and as far as politics needs religion, every religion needs a public manifestation.

As Diocletian and Maximian were deified by taking inspiration from the Olympus, and in particular from Jupiter and Hercules, Constantine wanted to be associated with god Sun and looked to the sky in a historical episode of $310 \mathrm{CE}$, possibly occurring in the Gallic sanctuary of Grand. ${ }^{5}$ The anonymous author who speaks of this fact mentions a divine apparition seen by Constantine in this Apollonian temple. After having dedicated some grants to the god because of the unexpected retreat of the barbarians, Constantine saw Apollo himself, who bestowed triumphal crown on him, each of whom forecasting a period of 30 years, i.e. three times the number ten. If we transform the words into symbols, we obtain a complete solar monogram with its full symbolic value. This solar symbol was successfully and subsequently borrowed by Christianity (fig. 1).

In this crucial phase of transition from a private to a public religion, Christianity got inspired by alphabetical combinations according to the Greek literary tradition. In Egypt the new religion discovered its vital symbol in the hieroglyphic writing by following a nostalgic claim and obtaining a consolatory result. ${ }^{7}$

\footnotetext{
${ }^{2}$ See DAVID: Una caupona (n. 1); DAVID, M.: Osservazioni sul banchetto rituale mitraico a partire dal Mitreo dei marmi colorati di Ostia antica. In Cuscito, G. (ed.): L'alimentazione nell'Antichità. Atti della XLVI settimana di studi aquileiesi. Aquileia, 14-16 maggio 2015 [Antichità Altoadriatiche 84], Trieste 2016, 173-184; DAVID, M.: Il pavimento del nuovo Mitreo dei marmi colorati a Ostia antica. In ANGelelli-Massara-Sposito (n. 1) 369-376 (with D. Abate, S. De Togni, M.S. Graziano, D. Lombardo, A. Melega, A. Pellegrino); DE Togni, S. - MelegA, A.: I nuovi mosaici pavimentali della Caupona del dio Pan a Ostia antica e l'architettura d'interni nel III sec. d.C. In ANGELELLI, C. - MASSARA, D. - PARIBENI, A. (edd): Atti del XXII colloquio dell'Associazione italiana per lo studio e la conservazione del mosaico. Matera, 16-19 marzo 2016. Tivoli 2017, 569-578 (with M. S. Graziano, D. Lombardo, M. Turci, J. Ferrandis Montesinos, G. P. Milani).

${ }^{3}$ One of these looks like a clear invocation to Mithras and Kronos by a man named Concordius; see DAVID: Una caupona (n. 1) 38.

${ }^{4}$ See BeCATTI, G.: Scavi di Ostia. II: I mitrei. Roma 1954, 139.

${ }^{5}$ See Pan. Lat. VII [6] 21.

${ }^{6}$ An evidence is the solar monogram represented in the mosaic of the triumphal arch of the church of S. Vitale in Ravenna, built in the mid-6th century CE.

${ }^{7}$ The reference is to Egyptian ankh; see MAZzOLENI, D.: Origine e cronologia dei monogrammi: riflessi nelle iscrizioni dei Musei Vaticani. In Di STEFANO MANZELla, I. (ed.): Le iscrizioni dei Cristiani in Vaticano. Materiali e contributi scientifici per una mostra epigrafica [Inscriptiones Sanctae Sedis 2]. Città del Vaticano 1997, 165-171, and MAZzolEni, D. in BisconTI, F. (ed.): Temi di Iconografia Paleocristiana [Sussidi allo Studio delle Antichità Cristiane XIII]. Città del Vaticano 2000, 221-223 s.v. Monogramma.
} 


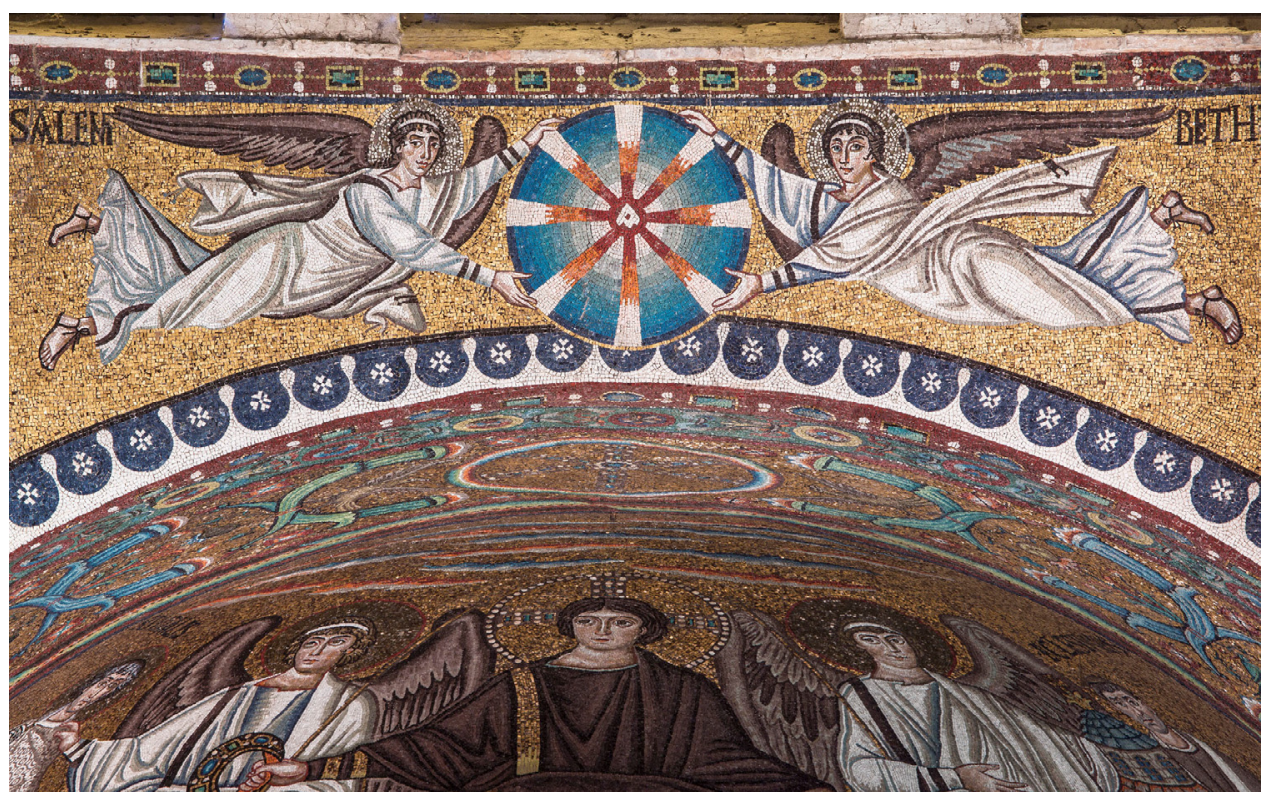

Fig. 1. Ravenna, S. Vitale. Solar monogram from the mosaic of the triumphal arch. 6th century CE (foto BAMS Rodella)
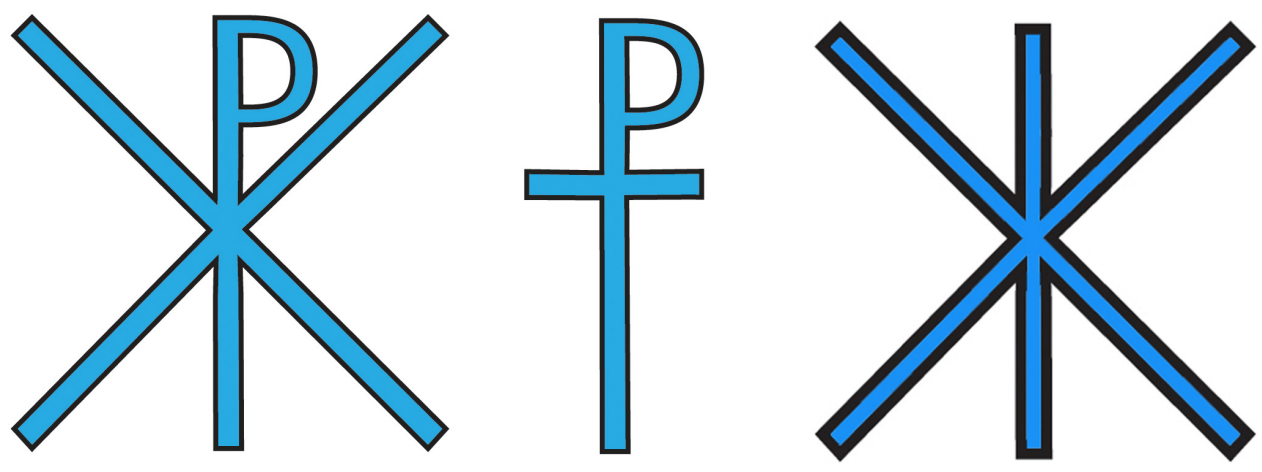

Fig. 2. Christian monograms (drawings by A. Melega)

Along with the Constantinian-Eusebian monogram, joining the first two letters of the Greek name of Jesus, also the monogrammatic cross was highly appreciated (fig. 2). ${ }^{8}$ The salvific power of the Christian monogram, celebrated by Lactantius and Eusebius,

${ }^{8}$ About the types of Christian monograms, see MAZzOLENI: Origine (n. 7), Monogramma (n. 7), and BiSCONTI, F.: Il vessillo, il cristogramma: i segni della salvezza. In SENA CHIESA, G. (ed.): Costantino 313 d.C. L'editto di Milano e il tempo della tolleranza. Milano 2012, 60-64; GARIPZANOV, I.: Graphic Signs of Authority in Late Antiquity and Early Middle Ages, 300-900. Oxford 2018. 


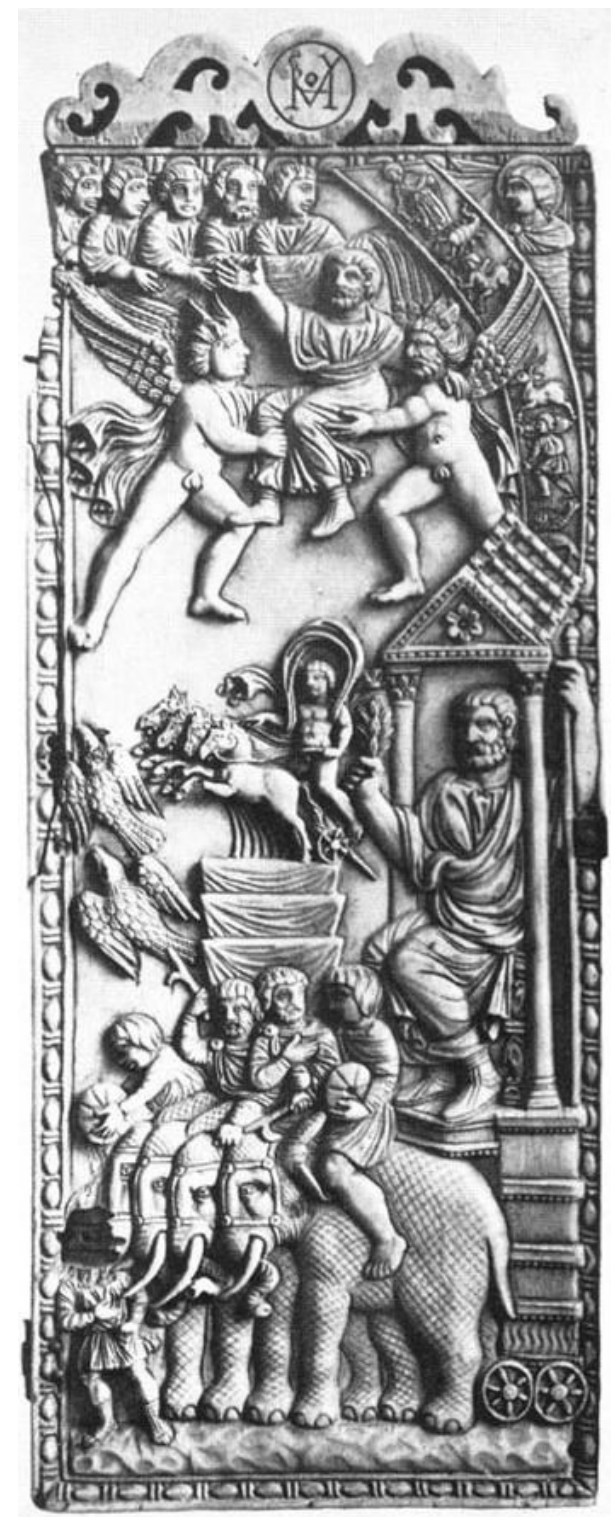

Fig. 3. London, British Museum. Ivory dyptich called "of the Consecratio", end of the 4th century CE

allowed him to be popular and wide-spread starting from the mid-4th century, and the vogue of the monogram got viral, reaching its peak in the 6th century. ${ }^{9}$ During the 4 th

${ }^{9}$ Consider for example the monogram of the Ravenna archbishop Maximian, represented on the bishop's ivory throne traditionally referred to him (Ravenna, Museo Arcivescovile). 
century, also some prominent families were involved in this trend, and transmitted their name by using monograms (fig. 3). According to Symmachus, in his famous letter to Nicomachus Flavianus, his monogram was complex and was aimed at urging the reader to intelligere, and not simply to read $^{10}$ (M. D.).

\section{MITHRAIC MONOGRAMS AT OSTIA}

On the basis of our research at Ostia it is possible to assert that Mithraism was also looking for a special public visibility by means of more or less complicated alphabetical signs. The so-called Mithraic monogram is documented according to three different types at Ostia, all of them refer to the name of the god, as in the case of Christ's name (fig. 4). These varying forms depend on the different writing forms of Mithras' name: Mithra, Mitrha, Mithras, Mythra, Mitra, Mytra, Methra. ${ }^{11}$

The first and more simple form shows the three first letters of Mithras' name in ligature, with the $T$ and the $I$ inserted at the center of the oblique lines of the $M$. Such a monogram is documented, as an abbreviation of the divine name, by two inscriptions from, respectively, the Mithraeum of Fructosus and the Aldobrandini Mithraeum. The first monogram, located South of the Decumanus, within a building with central porch and a temple on the backwall, bordered by the streets of the Pomerium and of the Round Temple, was written during the first half of the 3rd century CE in the temple's favissae. ${ }^{12}$ Its entire complex has been interpreted as the seat of a collegium, probably that of the stuppatores, i.e. producers of tow. The archaeological digging brought to light two fragments of the inscribed epistyle, wherein mention is made of the building a solo of a templum et spelaeum Mithrae, whose name is abbreviated with a monogram, by Fructosus, patronus of the guild (fig. 5). ${ }^{13}$ An early hypothesis of a templum for the collegium itself was followed by another one referring both the templum and the spelaeum to a Mithraeum. However, it is possible that the worshipper wanted to distinguish between these two areas, and spelaeum was the specific cultic area, whereas templum was the cultic place of a god related to Mithras, such as Sol invictus. In this case, we would be facing a peculiar connection, even though we know well some associations of Mithras with related deities. ${ }^{14}$

The Aldobrandini Mithraeum, whose chronology is uncertain, was dug within the estates of Aldobrandini family, a little North of Porta Romana, abutting the watercourse of the Tiber. ${ }^{15}$ Inspite of the scarcity of archaeological research in the Southern part of

\footnotetext{
${ }^{10}$ Symm. Ep. II 12; see MAZZOLENI: Origine (n. 7) 165.

${ }^{11}$ See the epigraphic index in VERMASEREN, M. J.: Corpus inscriptionum et monumentorum religionis Mithriacae I [CIMRM]. The Hague 1956, 347-348.

${ }^{12}$ See BeCATti (n. 4) 21-28 and CIMRM 117-118.

${ }^{13}$ [te]mpl(um) et spel(aeum) M(i)t(hrae) a solo sua pec(unia) feci(t). See CIL XIV 257 and CIL XIV 614; about the stuppatores guild see HERMANSEN, G.: The 'Stuppatores' and Their Guild in Ostia. AJA 86.1 (1982) 121-126.

${ }_{15}^{14}$ See BecAtTi (n. 4) 26-28.

${ }^{15}$ See BeCATTI (n. 4) 39-43 and CIMRM 119-120.
} 

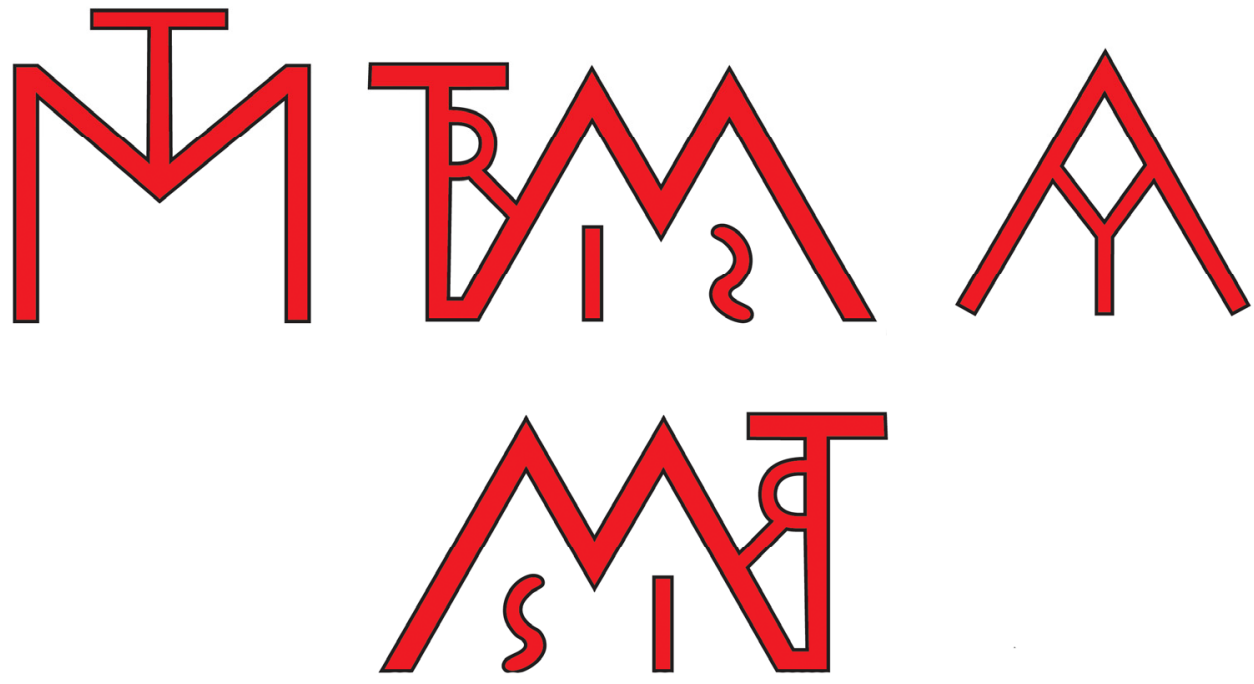

Fig. 4. Mithraic monograms from Ostia (drawings by A. Melega)

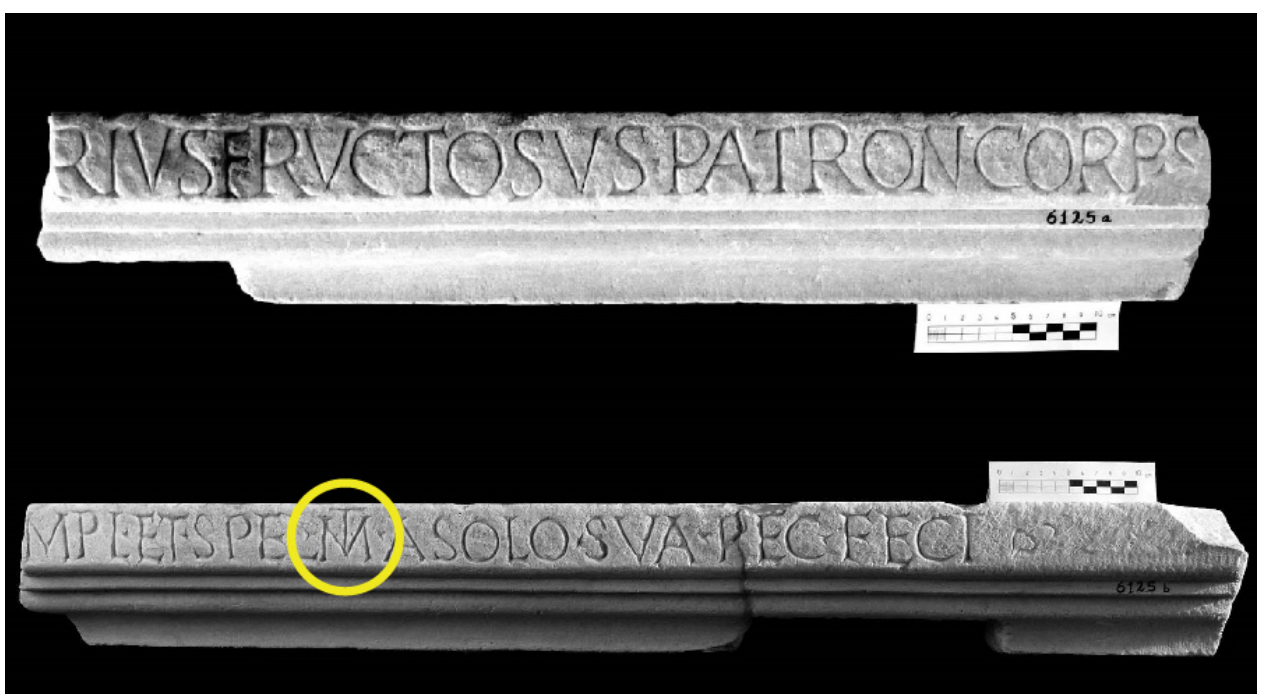

Fig. 5. Ostia, Mithraeum of Fructosus. Two fragments of the inscribed epistylium (the Mithraic monogram is highlighted)

this building, in order to avoid damages to the upper modern houses, it was possible to establish that the Mithraeum had been created out of a pre-existing room, abutting the Republican city walls. The hall probably underwent restaurations between the end of the 2nd and the beginning of the 3rd century CE, thanks to Sextus Pompeius Maxi$m u s$, Mithraic pater and rich patron, to whom a marble inscription and a bronze tablet 


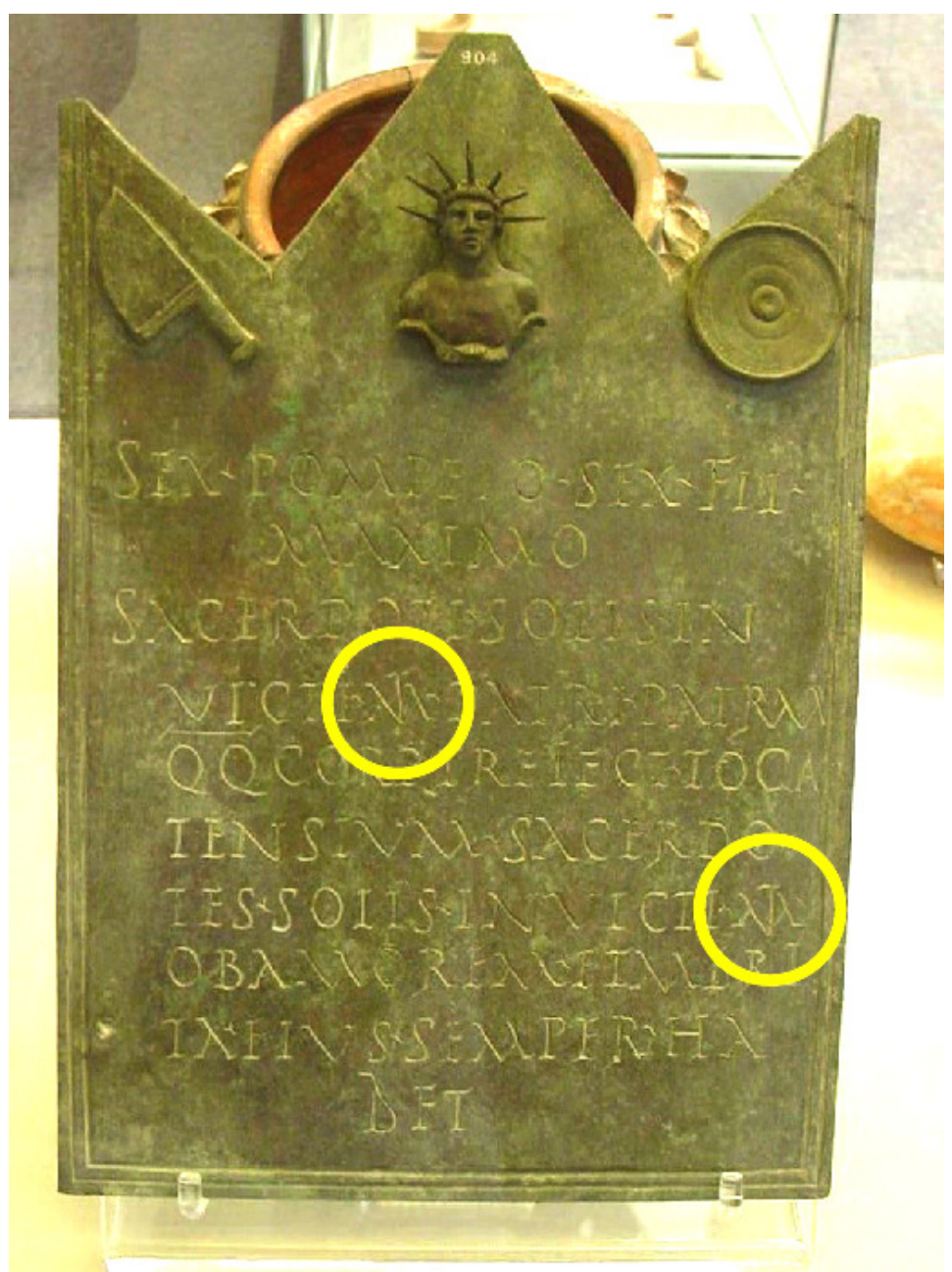

Fig. 6. London, British Museum. Inscribed bronze tablet

from the Aldobrandini Mithraeum at Ostia (the Mithraic monograms are highlighted)

had been dedicated. This latter is now preserved in the British Museum and had been offered to the benefactor by the priests to Sol Invictus Mithra for his merits, and here the name of the god is mentioned twice by means of the above quoted monogram (fig. 6). ${ }^{16}$

It is necessary to underline that the monogram recurs in the context of a written text, as an abbreviation, and not alone.

${ }^{16}$ CIL XIV 403: Sex(to) Pompeio Sex(ti) fil(io) / Maximo / sacerdoti Solis in/victi Mit(hrae) / patri patrum / q(uin)q(uennali) corp(oris) traiec(tus) toga/tensium sacerdo/tes Solis invicti Mit(hrae) / ob amorem et meri/ta eius. Semper habet. 


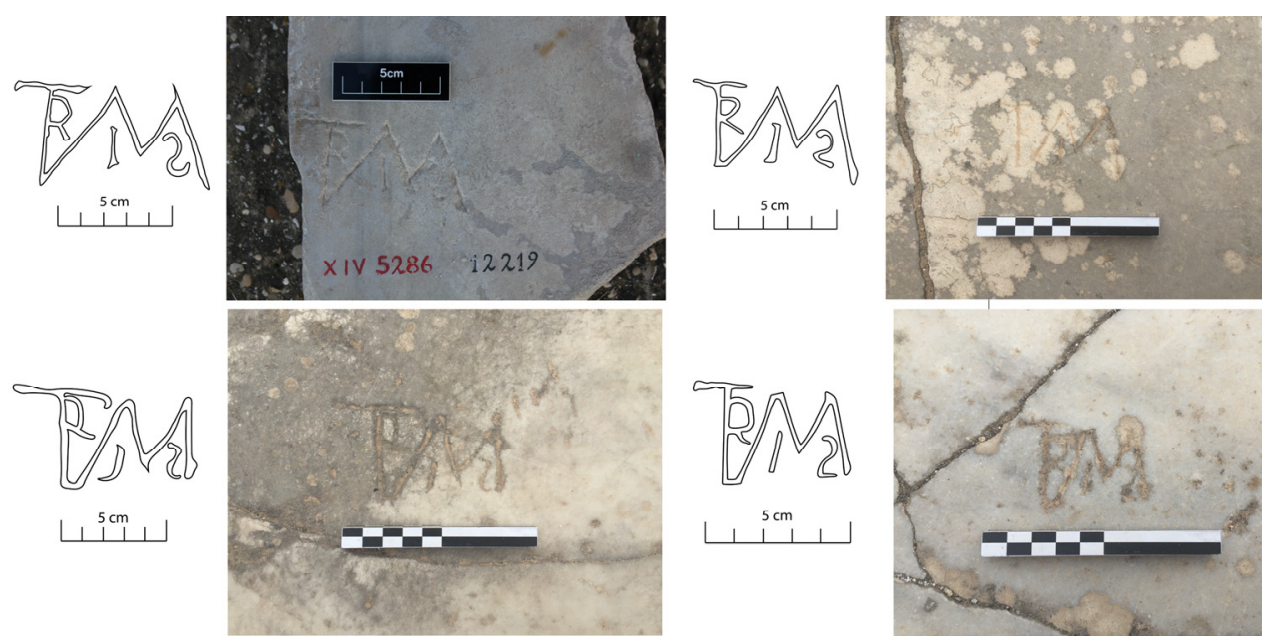

Fig. 7. Ostia, Baths of the Forum. Drawing and photograph of one of the Mithraic monograms (inv. 19753, 19754, 19755) (A. Melega)

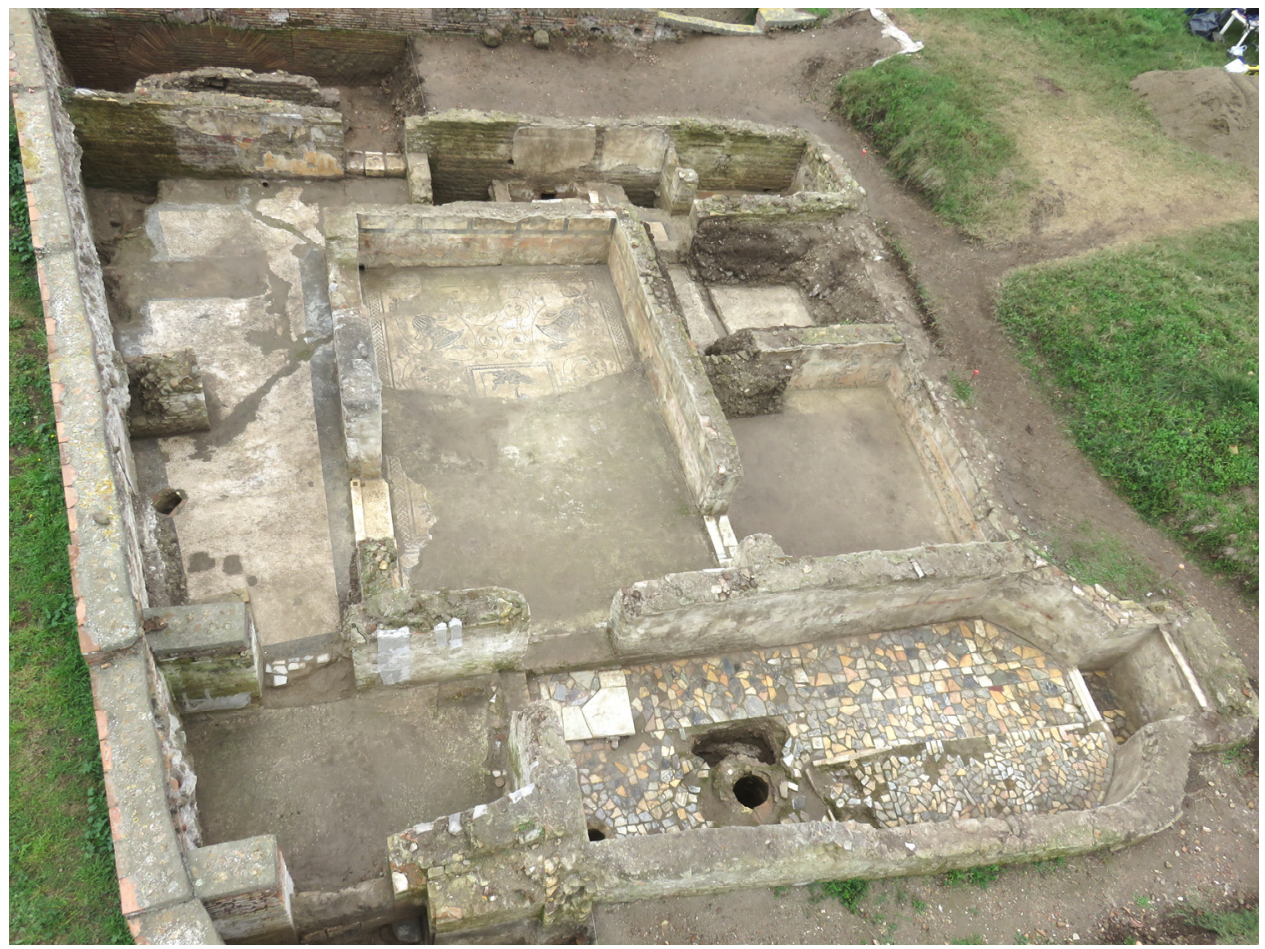

Fig. 8. Ostia. View of the Mithraeum of colored marbles 

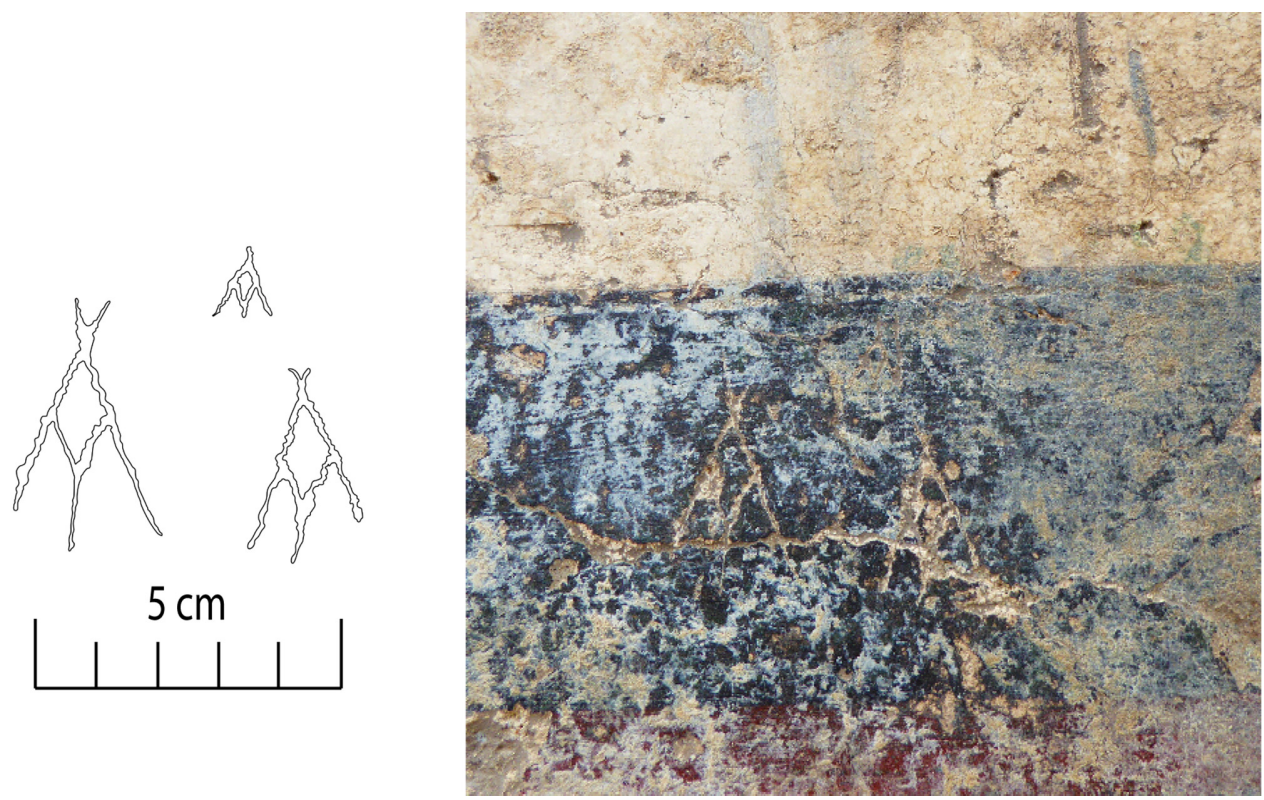

Fig. 9. Drawing and photograph of the graffito with monogram from the Mithraeum of colored marbles (A. Melega - M. David).

The second type is, instead, autonomous and indipendent from a text; it is complex and appears to be the result of the main letter, the $M$, at whose right the $T$, in ligature with $R$, is linked; the $I$ and the $S$ appear, respectively, on the left and on the right, in the triangular spaces under the $M$. In 1913, this particular monogram was first found on a marble slab out of context, during the excavation by Dante Vaglieri along the Decumanus, close to via dei Molini. ${ }^{17}$ More recently, the study dedicated to the Baths of the forum (Terme del foro) mentions three occurrences of this symbol: they are written on the marble floor of the rectangular tepidarium, which was laid during renovation works in the 3 rd century $\mathrm{CE}$ (fig. 7). ${ }^{18}$ It is an inverted monogram according to a custom documented in the Christian monograms, as well, which often reversed the letters alfa and omega. ${ }^{19}$ In any case, this monogram, even though known from the times of Vaglieri, has never been studied specifically.

The third type of monogram is documented by the recent discoveries in the Mithraeum of colored marbles (fig. 8). The southern wall of the large, central hall (room no. 3) preserves some monograms: in particular, we can see the letter $A$ framing the $M$ and the $Y$. This symbol recurs many times on this wall (fig. 9) (A. M.).

In the future, the Mithraeum of colored marbles will deserve much attention and research, specifically for the chronology of both the construction and the

${ }^{17}$ CIL XIV 5286; VAGLIERI, D.: Ostia. Scavo del decumano. Scoperte varie. NSc (1913) 204-220.

${ }^{18}$ See CicerchiA, P. - MARINUCCI, A.: Scavi di Ostia. XI: Le Terme del Foro o di Gavio Massimo. Roma 1992, 168, nn. C6, C7 and C8.

${ }^{19}$ See MAZZOLENI: Origine (n. 7) 166. 
abandonment phase. It is certain that these graffiti, along with its plan, its structure, and some syncretic elements, are important evidences in the frame of the current research about the late antique Ostia and the end of non-Christian cults (M. D. A. M.).

Massimiliano David

Alma Mater Studiorum - University of Bologna

Sapienza University of Rome

Italy

massimiliano.david@unibo.it

Alessandro Melega

Sapienza University of Rome

Italy

alessandro.melega@uniroma1.it 